\title{
An Analysis of Bank Financial Strength Ratings and Credit Rating Data ${ }^{\dagger}$
}

\author{
John A. Ruddy (1)
}

check for

updates

Citation: Ruddy, John A. 2021. An Analysis of Bank Financial Strength Ratings and Credit Rating Data. Risks 9: 155. https://doi.org/10.3390/ risks 9090155

Academic Editor: Mogens Steffensen

Received: 16 June 2021

Accepted: 23 August 2021

Published: 26 August 2021

Publisher's Note: MDPI stays neutral with regard to jurisdictional claims in published maps and institutional affiliations.

Copyright: (C) 2021 by the author. Licensee MDPI, Basel, Switzerland. This article is an open access article distributed under the terms and conditions of the Creative Commons Attribution (CC BY) license (https:// creativecommons.org/licenses/by/ $4.0 /)$.
Economics and Finance Department, Kania School of Management, University of Scranton, Scranton, PA 18510, USA; john.ruddy@scranton.edu; Tel.: +1-570-941-4043

† The present work is an extension of the paper "The Relation of Financial Markets and Bank Financial Strength Ratings" that I presented at the 2018 FMA Conference, San Diego, CA, USA, 10-13 October 2018.

\begin{abstract}
In this study, data from two credit rating agencies are analyzed to consider how different Bank Financial Strength Ratings and Credit Ratings from two rating agencies compare. To my knowledge, prior research has not analyzed Bank Financial Strength Ratings from different rating agencies, nor has it compared Bank Financial Strength Ratings to general credit ratings. These facts make this research unique. Univariate analyses are utilized to show relationships in the ratings data, along with parametric and non-parametric tests to make statistical inferences about the ratings data. There are five findings. First, ratings from different rating agencies are highly correlated. Second, different types of ratings from the same rating agency are highly correlated. Third, bank financial strength ratings are more conservative than credit ratings. Fourth, bank financial strength ratings declined in rating more quickly at the start of the financial crisis. Fifth, bank financial strength ratings from the Kroll Bond Rating Agency were more conservative than ratings from Moody's Investors Service. The research findings and results are important for investors who consider ratings agency data to determine the risk of banking institutions. The results are also important to businesses that rely on bank credit rating data and policy makers who regulate banking institutions.
\end{abstract}

Keywords: banking; credit ratings; rating agencies; bank financial strength ratings

\section{Introduction}

Bank Financial Strength Ratings (BFSRs) are a type of rating provided by Nationally Recognized Statistical Rating Organizations (NRSRO). BFSRs provide detailed metrics regarding a given bank's capital levels, asset quality, earnings, and liquidity. These variables, while not unique to banks, carry greater importance for banks than for non-banking entities. This research considers BFSRs from the Kroll Bond Rating Agency (KBRA) and Moody's Investors Service (Moody's). KBRA provides BFSRs on nearly all U.S. commercial banks. In 1995, Moody's was the first NRSRO to issue BFSRs. It provided BFSRs to businesses that were seeking information on the safety and soundness of other financial institutions. Moody's issued BFSRs in response to bank credit profile requests that ignored external support sources such as affiliated institutions or government aid. Poon et al. (1999) were among the first researchers to analyze BFSRs. The research utilized accounting and other financial data to predict BFSRs.

BFSRs and general credit ratings have similarities. Both are qualitative, non-numerical measures issued by rating agencies. Like BFSRs, prior research has attempted to predict and explain bank credit ratings (Gogas et al. 2014; Huang and Shen 2015; Poon et al. 2009). However, BFSRs and credit ratings also have differences. When compared to general credit ratings, BFSRs more closely reflect each bank's financial fundamentals. In contrast, credit ratings represent an evaluation of a given entity's overall credit risk, including external support factors. BFSRs indicate a bank's likelihood of needing external assistance to avoid default. External assistance could include contributions from an affiliate, shareholders 
or a government entity. BFSRs focus on key factors such as recent financial performance, its financial resources and the business environment in which the bank operates. They exclude external credit risk and support factors such as sovereign risk, currency transfer and/or conversion risk.

To avoid confusion, NRSROs have utilized different rating scales for BFSRs and credit ratings. KBRA utilizes a BFSR rating scale of " $\mathrm{A}+$ " through " $\mathrm{E}$ " to classify banks from strongest to weakest. KBRA assigns a rating value of "A+" to healthy institutions and assigns ratings of "E" to poorly performing institutions. Similarly, Moody's utilizes a BFSR rating scale of " $\mathrm{A}$ " through " $\mathrm{E}$ " to classify banking institutions from the strongest to the weakest. Appendix A Tables A1 and A2, Panels A and B contain a listing of each KBRA and Moody's BFSR along with a definition of each rating. While the letter ratings between KBRA and Moody's are similar, the description of rating letters can differ. Appendix A, Table A3, Panel C contains a mapping table, which equates the KBRA and Moody's BFSRs to Moody's credit ratings and a Weighted Average Rating Factor (WARF). WARF is a measure used by credit rating agencies to convert the qualitative rating information into a quantitative measure (Gluck et al. 2000; Morningstar 2017). NRSROs often utilize WARFs to rate structured products transactions such as collateralized loan obligations (CLOs).

This research adds to the body of literature by comparing BFSRs from different NRSROs. It also compares BFSRs to general credit ratings. To my knowledge, previous research has not considered either type of comparison. BFSRs are compared in an attempt to examine the similarities and differences in the BFSRs of two NRSROs. KBRA and Moody's BFSRs are also compared to Moody's credit ratings to examine the similarities and differences between BFSRs and credit ratings. The research objective is to obtain a better under-standing of BFSRs provided by different NRSROs and to obtain a better understanding of how BFSRs and credit ratings compare with one another. The research holds importance for businesses that use rating data to make decisions regarding bank transactions, and for regulators and managers who consider appropriate policies and risk levels for banking institutions.

In this research, different ratings provided by NRSROs are compared to provide a deeper understanding of BFSRs. Prior research has considered what variables are associated with BFSRs (Peresetsky and Karminsky 2008; Poon et al. 1999). BFSRs from two NRSROs and a NRSRO credit rating are compared for a set of financial institutions from 2001 through 2012. Then, whether the paired ratings are significantly different is tested using both parametric and non-parametric tests. BFRSs are more conservative (lower rated) than general credit ratings on the same set of banks. KBRA had more conservative (lower rated) BFSRs than Moody's BFSRs.

This study is organized as follows: Section 1 consists of background information and a brief introduction. Section 1 also contains a review of related literature as well as a hypothesis development. Section 2 details the data sources and research methodology. Section 3 provides an analysis and results. Section 4 provides a discussion and Section 5 provides conclusions.

\subsection{Literature Review}

BFSRs have existed for about 25 years since Moody's created the specialized rating in 1995. Poon et al. (1999) utilized logistic regression models to explain and predict BFSRs. The research utilized bank specific accounting and financial data to conclude that BFSRs contain the same information provided by credit ratings. Demirgüç-Kunt et al. (2008) concluded that countries with stronger bank regulators had superior Moody's BFSRs. Peresetsky and Karminsky (2008) reverse engineered Moody's BFSRs and long-term deposit ratings using econometric models. The research used only publicly available information that included asset quality, bank efficiency, bank size, capital adequacy, country specific economic data and bank profitability measures. The research found strong predictive power in the models. Hammer et al. (2012) utilized country risk ratings, bank overheads, profit before tax and 
return on average assets to assess bank creditworthiness. Hammer et al. (2012) found that ordered logistic regressions provided superior results.

Researchers have used publicly available data to explain bank credit ratings (Gogas et al. 2014; Öğüt et al. 2012). Öğüt et al. (2012) used bank financial statement data to predict Turkish bank BFSRs. The research concluded that bank efficiency, profitability and the loans to total asset metrics possessed the most explanatory power for Moody's BFSRs. Gogas et al. (2014) used publicly available financial statement data to predict long-term bank credit ratings. More recently, Ruddy (2018a) used a bank regulatory approach to explain BFSRs in over 6000 U.S. banks. The research utilized financial statement data as proxies from each of the areas of capital, asset quality, management, earnings, liquidity and sensitivity to market risk to explain BFSRs.

As ratings from both KBRA and Moody's are compared in this research, it is important to consider prior research that compares ratings from different rating agencies. Comparisons of credit ratings from different rating agencies is common in the literature. Beaver et al. (2006) compared the ratings provided by NRSROs to ratings provided by non-NRSRO rating agencies and found the ratings provided by NRSROs are more conservative than those provided by non-NRSROs. Jewell and Livingston (1999) conducted a comparison of Moody's, S\&P and Fitch bond ratings and found that the bond market valued ratings from all three rating agencies. Conversely, when comparing multiple credit ratings on the same instrument, Bongaerts et al. (2012) found that additional credit ratings provide no significant additional information. Gaillard (2012) compared sovereign bond ratings from Fitch, Moody's and S\&P and found that Moody's disagreed with the financial markets more than S\&P and Fitch. Gaillard (2012) also found that credit spread reactions were largest due to S\&P downgrades and Moody's upgrades. Reusens and Croux (2017) also analyzed sovereign credit ratings of the three major credit rating agencies and found evidence that the agencies changed their rating criteria after the European debt crisis.

Criticisms of rating agencies and/or the ratings systems is also common in the literature. Cantor and Packer (1997) found that, even though regulations assume ratings are equivalent between different rating agencies, some agencies consistently assign higher ratings than other agencies. Partnoy $(1999,2002)$ criticizes the bank regulatory dependence on NRSRO ratings. As a result, this research found that rating agencies wield great influence and reap large benefits. Johnson (2004) found that other credit rating agencies were able to predict NRSRO downgrades to below investment grade ratings. Johnson (2004) also found the tendency of NRSROs to be slow to signal firm problems and to make rating changes. Mathis et al. (2009) found that reputational concerns are insufficient incentives for rating agencies to avoid lax ratings. Most Recently, Partnoy (2017) concluded that the rating agency issues that contributed to the 2009 financial crisis have persisted.

Here BFSRs from different rating agencies are analyzed and compared, as are BFSR to credit ratings. To my knowledge, neither type of analysis has been previously performed. While prior research has compared credit ratings from different NRSROs, BFSRs are analyzed here from different NRSROs to provide a deeper understanding of BFSRs. Research is conducted to determine if BFSRs provide additional information to credit ratings alone.

\subsection{Hypotheses}

Prior research on BFSRs indicates that BFSRs do not provide any new information to the financial markets. (Öğüt et al. 2012; Peresetsky and Karminsky 2008; Poon et al. 1999) found that other credit rating data combined with financial statement data can replicate the information provided by BFSRs. Similarly, Peresetsky and Karminsky (2008) were able to reverse engineer Moody's BFSRs using only public available data. They used accounting and financial data including asset quality and bank asset size to provide their models with predictive power. Ögüt et al. (2012) used publicly available financial statement data to predict the BFSRs of Turkish banking institutions. 
NRSROs utilize publicly available banking data to create BFSRs. NRSROs issue BFSRs that reflect each bank's current financial strength. Stated differently, BFSRs reflect each financial institution's currently available mix of financial information. Since BFSRs are based on publicly available information, the BFSR strength ratings from different rating agencies should be consistent with each other. In addition, BFSRs from different rating agencies should move in tandem with each other over time. They should also have similar ratings for the same set of financial institutions over time.

Therefore:

Hypothesis 1 (H1). KBRA and Moody's will have BFSRs that are consistent with each other over time for the same set of financial institutions.

BFSRs are similar, but not identical to, general credit ratings. The similarities between the ratings include the economic environment in which an institution operates and the quality of an institution's regulatory supervision. Both BFSRs and credit ratings are based, at least in part, on publicly available financial information. Examples include total asset size, asset quality, earnings, capital reserves and bank liquidity. Prior researchers have used publicly available information to reverse engineer both BFSRs and credit ratings (Gogas et al. 2014; Öğüt et al. 2012). Gogas et al. (2014) used publicly available financial statement data to predict bank long-term credit ratings. Öğüt et al. (2012) predict Turkish bank BFSRs using publicly available financial statement data. The differences between BFSRs and credit ratings are that BFSRs ignore external credit support factors, such as government support. As these factors would offer positive support for credit ratings, banks should have lower BFSRs than the equivalent credit rating, ceteris paribus.

Therefore:

Hypothesis 2 (H2). KBRA and Moody's BFSRs are more conservative (lower ratings) than the equivalent credit ratings over time for the same set of financial institutions.

\section{Materials and Methods}

In this section, the data and methodologies utilized in this research are described and data summary statistics provided.

\subsection{Data}

Two data sources are utilized for this research: Bloomberg terminal data and a onetime KBRA subscription, along with the same data utilized in the 2018 FMA Conference presentation by Ruddy (2018b).

\subsubsection{Kroll Bond Rating Association (KBRA)}

I accessed KBRA international bank rating data via a one-time subscription. The KBRA data contains 1345 ratings on 76 banking institutions. The most recent KBRA rating is from 11 January 2013 and the oldest rating is from 31 July 2000. The data set contains 489 BFSR changes. The list of 76 financial institutions with a KBRA rating is compared to the list of banks with Moody's credit ratings and Moody's BFSRs and a summary provided of statistics on the financial institutions by country, geographic region, and currency in Table 1.

\subsubsection{Bloomberg Data}

I utilized a Bloomberg terminal to acquire two different sets of data: (1). Moody's BFSRs and (2). Moody's Credit Ratings. The Moody's BFSR data contain 606 ratings on 71 institutions. The most recent Moody's BFSR is from 4 March 2014 and the oldest Moody's BFSR is from 2 August 1995. Moody's discontinued providing BFSRs in 2014 and withdrew its BFSRs in 2015. The Moody's credit rating data contains 731 ratings on 68 institutions. The most recent Moody's credit rating date is 8 August 2016 and the oldest 
Moody's credit rating is 17 January 1983. Accordingly, the Moody's credit rating dataset contains more ratings and covers a wider period than the Moody's BFSR data.

To conduct a univariate analysis, I compared KBRA BFSRs and Moody's BFSRs in 76 and 71 financial institutions, respectively. I also compared Moody's BFSRs and Moody's credit ratings in 71 and 68 institutions, respectively. Sixty-one institutions are common to both the KBRA and Moody's BFSR lists. Fifteen institutions are included in the KBRA data only (not on the Moody's BFSR list) and ten institutions are included in the Moody's data only (not on the KBRA BFSR list).

\subsection{Methodology}

I began my analysis by converting qualitative BFSRs and credit ratings into quantitative variables. As indicated in Section 1 above, I do this using a weighted average rating factor (WARF). NRSROs utilize WARF measures to rate structured product transactions, such as CLOs. Moody's was one of the first NRSROs to publish research utilizing a WARF methodology (Gluck et al. 2000). More recently, Morningstar (2017) outlined its CLO rating methodology by utilizing WARFs. Prior researchers have also utilized WARF to analyze credit rating data (Hrvatin et al. 2006; Hu 2007; Ruddy 2018a). In the rating conversion, I equate each BFSR to a Moody's credit rating equivalent. Converting the qualitative BFSRs to a WARF numerical measure allows the calculation of BFSR summary statistics. WARF is an estimate of the default rate for a given borrower at a given rating category. It thus measures the probability that a financial institution with a given BFSR will subsequently default. For example, an institution with a KBRA rating of "B-", translates to a Moody's credit rating of "Baa1" and a WARF of 260. Similarly, a bank rated "E" by KBRA converts to a Moody's rating of "Ca". Appendix A, Table A1, Panel A provides a list and description of each KBRA BFSR.

Once I have converted the BFSRs and credit ratings to quantitative data, I begin the data analysis. First, I performed a BFSR univariate analysis to better understand the behavior of BFSRs. In interrogative form: how do different BFSRs and different NRSROs compare to one another over time? Similarly, how do BFSRs compare to credit ratings over time? Previous research has not compared different BFSRs or BFSRs to credit ratings. Thus, I determine if the variables have any association with BFSRs over the period studied. Second, I test whether BFSRs from different NRSROs are statistically different from each other by conducting paired tests of the ratings data. To determine if BFSRs from different NRSROs are statistically different, I perform parametric and non-parametric tests of paired ratings from the same set of financial institutions. More specifically, I conduct paired sample t-tests and Wilcoxon signed rank tests to determine if ratings from different NRSROs are statistically significant. I also pair BFSRs and credit ratings to determine if BFSRs are statistically significant from credit ratings on the same set of financial institutions. Whether different types of ratings and/or BFSRs from different NRSROs are different is important to businesses that transact with financial institutions. It also has importance for policymakers who regulate financial institutions and the capital market participants who invest in financial institutions. I provide a diagram of the research methodology in Figure 1 as follows: 


\begin{tabular}{|c|c|}
\hline 1. Data Collection & $\begin{array}{c}\text { Record ratings data for } \\
\text { banks over period of study }\end{array}$ \\
\hline Utilize KBRA subscription and Bloomberg terminal &
\end{tabular}

\begin{tabular}{|c|c|}
\hline 2. Data Conversion & $\begin{array}{c}\text { Use WARF methodology } \\
\text { to quantify ratings data }\end{array}$ \\
\hline Convert qualitative ratings into quantitative measures &
\end{tabular}

\begin{tabular}{|c|c|}
\hline 3. Summary Statistics & Breakdown the ratings data by \\
\cline { 1 - 1 } Provide summary statistics on banking institutions & region, CDS currency \& country \\
\hline
\end{tabular}

\begin{tabular}{|c|c|}
\hline 4. Univariate Analyses & $\begin{array}{l}\text { Compare average ratings and } \\
\text { calculate correlation statistics }\end{array}$ \\
\hline Compare different ratings data over period of study &
\end{tabular}

\begin{tabular}{|c|l|}
\hline 5. Statistical Analysis & $\begin{array}{l}\text { Compute statistical significance } \\
\text { and make statistical inferences }\end{array}$ \\
\hline Run parametric and non-parametric tests & and
\end{tabular}

Figure 1. Research Methodology Diagram.

\subsection{Summary Statistics}

I provide summary statistics on the data outlined above in Section 2.1, breaking down the list of financial institutions by geographic region, credit default swap (CDS) currency and by country. Table 1 includes summary statistics on the institutions with a KBRA BFSR, Moody's BFSRs and Moody's credit ratings.

Table 1 contains summary statistics on banking institutions by geographic region (Panel A), currency (Panel B) and by country (Panel C). Each panel contains the summary statistics for banks with a KBRA BFSR, Moody's BFSR and Moody's credit rating.

Table 1, Panel A provides a breakdown of the ratings data by geographic region. Each institution's geographic region is based on its global headquarters location. Europe is the region with the most institutions in the data set. More specifically, Europe has 41 banks with KBRA BFSRs, 44 banks with Moody's BFSRs and 43 banks with Moody's credit ratings. In contrast, the Americas region contains the lowest number of banks of any region. It has seven banks with KBRA BFSRs, one bank with a Moody's BFSR, and one bank with a Moody's credit rating.

Table 1, Panel B, provides the primary CDS currency for each bank. I obtained Bloomberg CDS spread data for each bank. Bloomberg provided the data in either Euros or U.S. Dollars (USD). As I indicate in Panel B, 34 of the banks with KBRA BFSRs have CDS spread data primarily quoted in USD and 42 banks with KBRA BFSRs have CDS spread data primarily quoted in Euros. As I also indicate in Panel B, 26 of the banks with Moody's BFSRs have CDS spread data primarily quoted in USD and 45 institutions with Moody's BFSRs have CDS spread data quoted in Euros. Lastly, Panel B indicates that 24 banks with Moody's credit ratings have CDS spread data primarily quoted in USD and 44 banks have CDS spread data primarily quoted in Euros.

Table 1, Panel C provides summary statistics on the data by country. I assigned institutions to a given country based on global headquarters location. Germany contains the largest number of banks with nine KBRA BFSRs, nine Moody's BFSRs and nine Moody's credit ratings. Several different countries have the smallest financial institution count of any country with one KBRA BFSR, one Moody's BFSR and one Moody's credit rating, respectively. Examples include Greece and Denmark. 
Table 1. KBRA and Moody's Summary Statistics.

\begin{tabular}{|c|c|c|c|c|c|}
\hline \multicolumn{6}{|c|}{ Panel A: Summary Statistics by Geographic Region } \\
\hline Number & \multicolumn{2}{|c|}{ Region } & $\begin{array}{l}\text { KBRA } \\
\text { BFSRs }\end{array}$ & $\begin{array}{l}\text { Moody's } \\
\text { BFSR }\end{array}$ & $\begin{array}{c}\text { Moody's Credit } \\
\text { Ratings }\end{array}$ \\
\hline 1 & \multicolumn{2}{|c|}{ Americas } & 7 & 1 & 1 \\
\hline 2 & \multicolumn{2}{|c|}{ Europe } & 41 & 44 & 43 \\
\hline 3 & \multicolumn{2}{|c|}{ Middle East } & 8 & 8 & 8 \\
\hline 4 & \multicolumn{2}{|c|}{ Pacific } & 20 & 18 & 16 \\
\hline Total & & & 76 & 71 & 68 \\
\hline \multicolumn{6}{|c|}{ Panel B: Summary Statistics by Currency } \\
\hline Number & \multicolumn{2}{|c|}{ Currency } & $\begin{array}{l}\text { KBRA } \\
\text { BFSRs }\end{array}$ & $\begin{array}{l}\text { Moody's } \\
\text { BFSR }\end{array}$ & $\begin{array}{l}\text { Moody's Credit } \\
\text { Ratings }\end{array}$ \\
\hline 1 & \multicolumn{2}{|c|}{ EUR } & 42 & 45 & 44 \\
\hline 2 & \multicolumn{2}{|c|}{ USD } & 34 & 26 & 24 \\
\hline Total & & & 76 & 71 & 68 \\
\hline \multicolumn{6}{|c|}{ Panel C: KBRA Summary Statistics by Country } \\
\hline Number & Country & Region & $\begin{array}{l}\text { KBRA } \\
\text { BFSRs }\end{array}$ & $\begin{array}{c}\text { Moody's } \\
\text { BFSR }\end{array}$ & $\begin{array}{c}\text { Moody's Credit } \\
\text { Ratings }\end{array}$ \\
\hline 1 & Australia & Pacific & 5 & 6 & 6 \\
\hline 2 & Bahrain & Middle East & 1 & 1 & 1 \\
\hline 3 & Belgium & Europe & 2 & 2 & 2 \\
\hline 4 & China & Pacific & 2 & 2 & 1 \\
\hline 5 & Denmark & Europe & 1 & 1 & 1 \\
\hline 6 & France & Europe & 4 & 4 & 4 \\
\hline 7 & Germany & Europe & 9 & 9 & 9 \\
\hline 8 & Greece & Europe & 1 & 1 & 1 \\
\hline 9 & India & Pacific & 4 & 2 & 2 \\
\hline 10 & Ireland & Europe & 2 & 2 & 2 \\
\hline 11 & Italy & Europe & 7 & 7 & 7 \\
\hline 12 & Japan & Pacific & 3 & 2 & 2 \\
\hline 13 & Korea & Pacific & 4 & 4 & 3 \\
\hline 14 & Netherlands & Europe & 3 & 3 & 2 \\
\hline 15 & Norway & Europe & 1 & 1 & 1 \\
\hline 16 & Portugal & Europe & 2 & 2 & 2 \\
\hline 17 & Qatar & Middle East & 1 & 1 & 1 \\
\hline 18 & Russia & Pacific & 1 & 1 & 1 \\
\hline 19 & Saudi Arabia & Middle East & 2 & 2 & 2 \\
\hline 20 & Spain & Europe & 2 & 4 & 4 \\
\hline 21 & Sweden & Pacific & 4 & 4 & 4 \\
\hline 22 & Switzerland & Europe & 1 & 1 & 1 \\
\hline 23 & UAE & Middle East & 4 & 4 & 4 \\
\hline 24 & United Kingdom & Europe & 3 & 4 & 4 \\
\hline 25 & United States & Americas & 7 & 1 & 1 \\
\hline Total & & & 76 & 71 & 68 \\
\hline
\end{tabular}




\section{Analyses and Results}

I conduct analyses to consider the relationships in the NRSRO data. More specifically, I compare BFSRs to other BFSRs and BFSRs to general credit ratings to see if any associations exist between NRSRO ratings.

\subsection{Univariate Analyses}

I conducted two univariate analyses. First, I conducted a comparison of KBRA BFSRs and Moody's BFSRs for the period from 1 December 2001 to 1 December 2012. I provide the differences between the KBRA and Moody's WARFs over time in Figure 2.

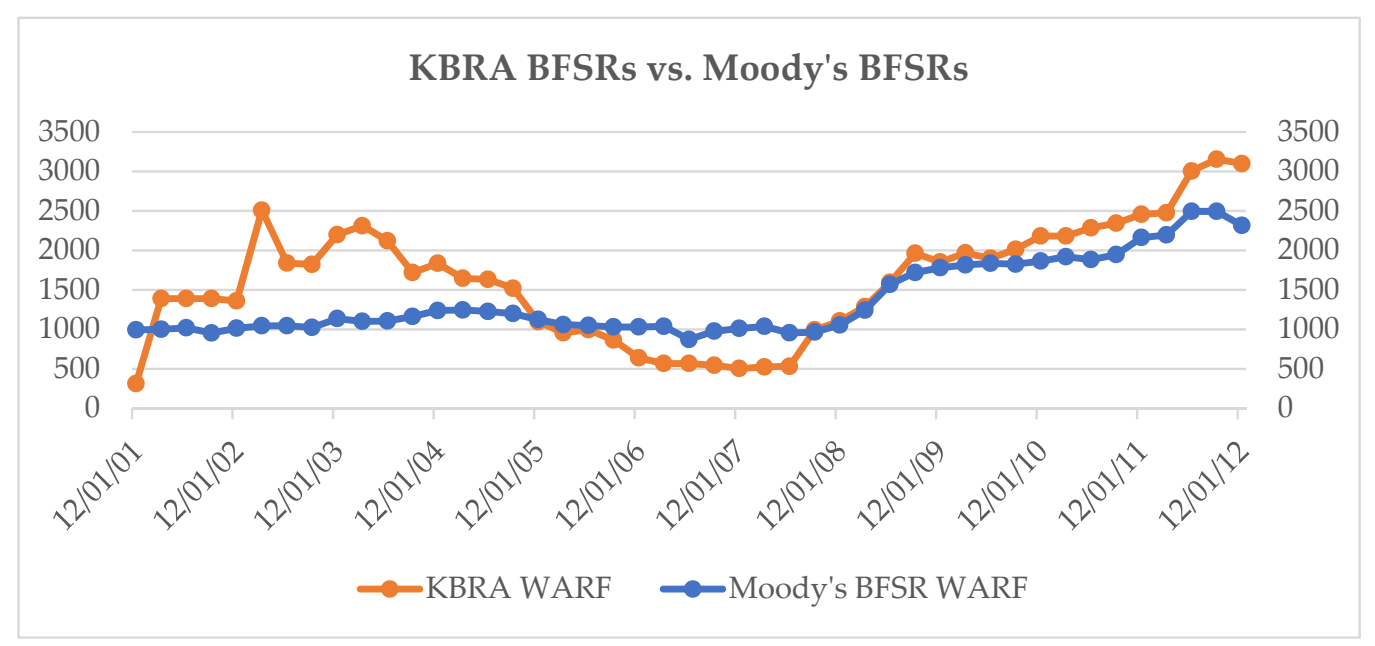

Figure 2. KBRA BFSR vs. Moody's BFSR.

The figure below provides a comparison of KBRA BFSRs and Moody BFSRs. The figure shows BFSR changes based on quarterly ratings data from 31 December 2001 to 31 December 2012, inclusive.

As Figure 2 indicates, the KBRA and Moody's BFSRs are highly correlated. Using a quarterly frequency from 31 December 2001 to 31 December 2012, the BFSRs have a Pearson's correlation coefficient of $+77.9 \%$. When the paths are considered in Figure 2, it is evident that the two variables move in near lockstep with one another. What is also evident from Figure 2 is that the KBRA WARF was higher than the Moody's WARF from 2002 to 2005. On 31 March 2003 the KBRA WARF was 2509 while the Moody's WARF on the same date was 1045. This means that, as of the first quarter of 2003, KBRA provided an average rating of between B1 and B2 while Moody's gave the same banks an average rating of between $\mathrm{Ba} 1$ and $\mathrm{Ba} 2$. This is a rating difference of three notches. Over the next 10 quarters, the rating differences between the KBRA and Moody's WARF narrowed. As a result, the KBRA and Moody's WARFs were nearly identical in 2006. By the beginning of the credit crisis, the difference in KBRA and Moody's ratings reversed such that Moody's had a higher WARF. In the 4th quarter of 2007, the Moody's WARF was 1012 and the KBRA WARF was 505. KBRA had a significant WARF increase from 532 in the second quarter of 2008 to 994 in the third quarter of 2008. WARFs Moody's did not have a commensurate increase, as its WARF went from 956 in the second quarter of 2008 to 965 in the third quarter of 2008. From 2009 through the beginning of 2012, the KBRA and Moody's WARFs were, once again, nearly identical. Over the 45 quarters from 31 December 2001 to 31 December 2012 inclusive, KBRA had a higher average WARF. The average KBRA WARF was 1615 while the average Moody's WARF was 1374. This difference indicates that, on average, KBRA had more conservative (lower) BFSR ratings than did Moody's over the period of study.

The second univariate analysis involved comparing Moody's BFSRs to Moody's general credit ratings during the period 3 March 2002 to 31 December 2012. I provide the differences between the KBRA and Moody's WARFs over time in Figure 3. 


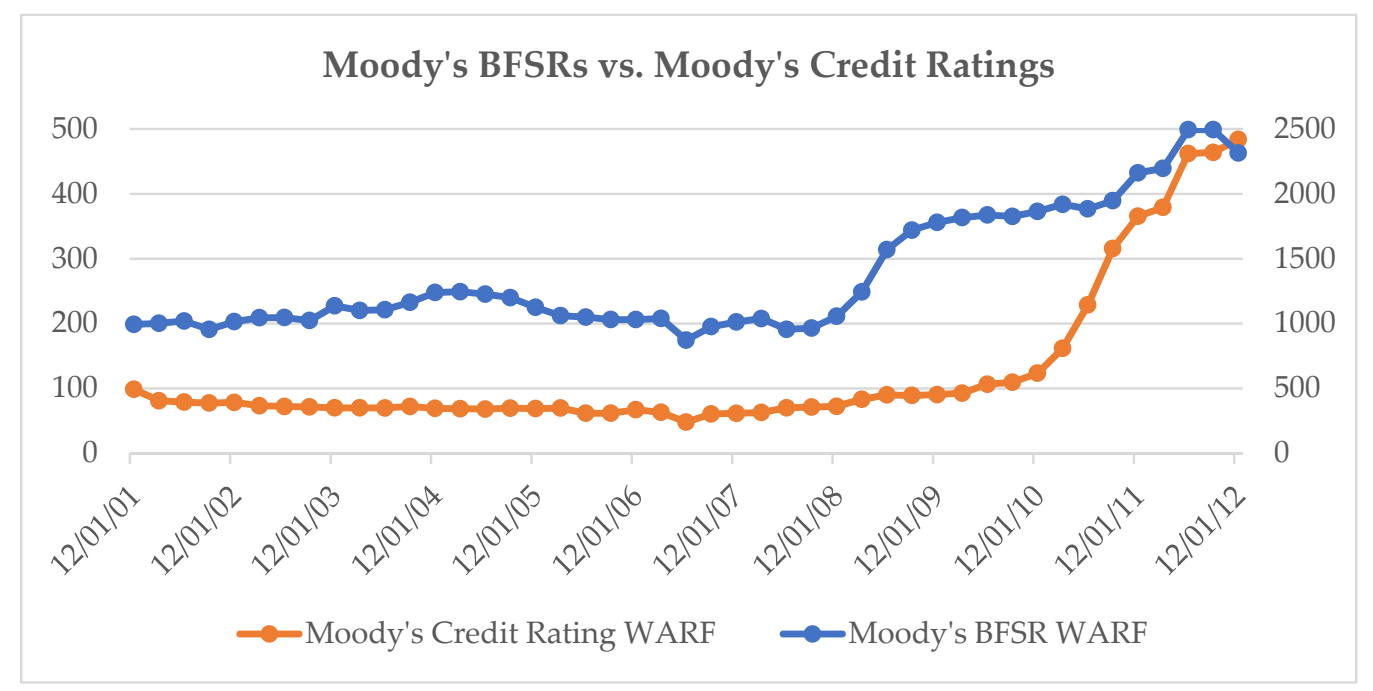

Figure 3. Moody's BFSRs vs. Moody's Credit Ratings.

The figure below provides a comparison of the WARFs of Moody's BFSRs and Moody's credit ratings. The graph shows BFSR changes based on quarterly data from 31 December 2001 through 31 December 2012, inclusive. The left side axis pertains to Moody's credit ratings and the right side axis pertains to Moody's BFSRs.

As Figure 3 indicates, the WARF using Moody's BFSRs and Moody's credit ratings are highly correlated. The two variables have a Pearson's correlation coefficient equal to $+85.4 \%$ over the period of study. When the paths are considered in Figure 3, it is evident that the two variables move in near lockstep with one another. What is also evident from Figure 3 is that the Moody's BFSR WARF increased in 2008 and 2009 while the Moody's credit ratings WARF had little change. The Moody's BFSR WARFs increased from 1039 in the first quarter of 2008 to 1780 in the fourth quarter of 2009. Over the same period, the Moody's credit rating WARF increased from 63 to 91 . This may indicate that BFSRs provided an earlier indication of trouble in banking institutions prior to credit ratings. Lastly, during the entire 2002-2012 period covered by Figure 3, Moody's BFSR WARF is higher than the Moody's credit ratings WARF. This relationship exists in each quarter from early 2002 through the end of the data series in 2012. For example, the Moody's BFSR WARF from the fourth quarter of 2012 is 2315 . The Moody's credit rating WARF for the same quarter is 484 . This means that, at the end of 2012, Moody's BFSRs indicated that the institutions were rated roughly B1 while Moody's credit ratings indicated a rating of between Baa2 and Baa3. Over the 45 quarters from 31 December 2001 through 31 December 2012 inclusive, the average Moody's BFSR WARF was 1374 while the average Moody's credit rating WARF was 126. This means that over the period studied, Moody's BFSRs on average rated banking institutions $\mathrm{Ba} 2$ while Moody's credit ratings on average rated banking institutions A2.

\subsection{Parametric and Nonparametric Tests}

The second type of analysis that I conducted involved parametric and nonparametric tests of paired ratings data. I did this to determine whether: 1 . BFSRs are statistically different from general credit ratings; 2 . BFSRs from different rating agencies are statistically different from each other. Specifically, I took matched pair BFSRs from KBRA and Moody's and determined if they were statistically different. I conducted a Wilcoxon signed rank test, which is a non-parametric test, as it makes no assumption about the distribution of the paired ratings data. For comparison purposes, I also conducted paired t-tests for two sample means. Unlike the Wilcoxon signed ranked test, paired t-tests assume that the paired ratings are normally distributed. As I needed paired data to run both the Wilcoxon signed rank and paired t-tests, I used only a subset of the dataset described in Section 2 titled Materials and Methods. For example, if I were comparing 2010 KBRA BFSRs and 
2010 Moody's BFSRs, the data included only those institutions for which I had both ratings at the end of 2010. I present the results of both tests in Table 2 as follows.

Table 2. Results of Parametric and Nonparametric Testing.

\begin{tabular}{|c|c|c|c|c|c|c|c|c|c|}
\hline \multirow[b]{3}{*}{ Year } & \multicolumn{3}{|c|}{ A. KBRA BFSRs } & \multicolumn{3}{|c|}{ B. KBRA BFSRs } & \multicolumn{3}{|c|}{ C. Moody's BFSRs } \\
\hline & \multicolumn{3}{|c|}{ vs. Moody's BFSRs } & \multicolumn{3}{|c|}{ vs. Moody's Credit Ratings } & \multicolumn{3}{|c|}{ vs. Moody's Credit Ratings } \\
\hline & $\mathbf{N}$ & Wilcoxon & t-Test & $\mathbf{N}$ & Wilcoxon & t-Test & $\mathbf{N}$ & Wilcoxon & t-Test \\
\hline $2001 \& 2002$ & 12 & $0.008^{* * *}$ & $0.089 *$ & 6 & $0.027 * *$ & 0.325 & 47 & $0.000 * * *$ & $0.014^{* *}$ \\
\hline 2003 & 20 & $0.061 *$ & 0.296 & 12 & $0.000 * * *$ & $0.044^{* *}$ & 26 & $0.000 * * *$ & $0.054^{*}$ \\
\hline 2004 & 41 & 0.119 & 0.198 & 24 & $0.000 * * *$ & $0.012 * *$ & 28 & $0.000 * * *$ & $0.028 * *$ \\
\hline 2005 & 43 & 0.706 & 0.970 & 26 & $0.000^{* * *}$ & $0.001^{* * *}$ & 31 & $0.000 * * *$ & $0.007^{* * *}$ \\
\hline 2006 & 41 & 0.218 & 0.318 & 29 & $0.000 * * *$ & $0.000^{* * *}$ & 32 & $0.000^{* * *}$ & $0.003^{* * *}$ \\
\hline 2007 & 47 & $0.022 * *$ & $0.089 *$ & 31 & $0.000^{* * *}$ & $0.003^{* * *}$ & 33 & $0.000^{* * *}$ & $0.000^{* * *}$ \\
\hline 2008 & 55 & 0.325 & 0.566 & 37 & $0.000 * * *$ & $0.007^{* * *}$ & 36 & $0.000^{* * *}$ & $0.000^{* * *}$ \\
\hline 2009 & 56 & 0.916 & 0.315 & 39 & $0.000^{* * *}$ & $0.000^{* * *}$ & 38 & $0.000 * * *$ & $0.000^{* * *}$ \\
\hline 2010 & 57 & 0.700 & $0.095 *$ & 39 & $0.000^{* * *}$ & $0.000^{* * *}$ & 39 & $0.000 * * *$ & $0.000 * * *$ \\
\hline 2011 & 57 & 0.471 & 0.529 & 39 & $0.000 * * *$ & $0.000^{* * *}$ & 39 & $0.000 * * *$ & $0.000 * * *$ \\
\hline 2012 & 57 & 0.211 & 0.680 & 39 & $0.000 * * *$ & $0.000^{* * *}$ & 39 & $0.000 * * *$ & $0.000 * * *$ \\
\hline All Years & 486 & 0.177 & 0.070 * & 321 & $0.000 * * *$ & $0.000^{* * *}$ & 388 & $0.000^{* * *}$ & $0.000 * * *$ \\
\hline
\end{tabular}

${ }^{*}$ indicates significance at the $p$-level of $0.10,{ }^{* *}$ indicates significance at the $p$-level of $0.05,{ }^{* * *}$ indicates significance at the $p$-level of 0.01 .

The below table contains the results of parametric and non-parametric testing. Panel A contains the results when comparing KBRA BFSRs and Moody's BFSRs; Panel B contains the results when comparing KBRA BFSRs and Moody's Credit ratings; Panel C contains the results when comparing Moody's BFSRs and Moody's Credit ratings.

As Table 2 indicates, I conducted three sets of Wilcoxon and paired t-tests as follows: 1. KBRA BFSRs vs. Moody's BFSRs; 2. KBRA BFSRs vs. Moody's credit ratings; and 3. Moody's BFSRs vs. Moody's credit ratings. The first set of tests is KBRA BFSRs vs. Moody's BFSRs, which is a difference between how two NRSROs used BFSRs to rate the same set of financial institutions. As was highlighted in the above univariate analysis section, the average KBRA BFSR was higher than the average Moody's BFSR in 33 out of 45 quarters during the 2001-2012 period. The question addressed by the signed Wilcoxon and paired t-tests is whether the differences are statistically different when analyzed as paired ratings. As a result, I compared pairs of BFSRs from KBRA and Moody's. For the Table 2 presentation, I combined the 2001 and 2002 results. For panel A, I located matched pairs of KBRA and Moody's BFSR ratings. I converted the qualitative ratings to a quantitative measure using Moody's WARF methodology. I then compared the paired ratings data. I conducted a Wilcoxon Signed rank test and paired t-tests on the same pairs of data. For 2003, I tested 20 pairs of ratings. The result is a Wilcoxon $p$ value of 0.061 and a paired t-tests $p$ value of 0.296 . For the twelve periods displayed in Panel A, the Wilcoxon test indicates statistical significance of at least $10 \%$ in three periods and the paired t-tests indicates statistical significance of at least $10 \%$ in four periods. This means that four of the 12 periods indicate significantly different BFSRs on the same set of financial institutions for KBRA and Moody's.

The second set of statistical tests involved a comparison of KBRA BFSRs and Moody's credit ratings. As was highlighted in the above univariate analysis section, the average KBRA BFSR was higher than the average Moody's credit ratings in the 45 quarters during the 2001-2012 period. To determine whether KBRA BFSRs and Moody's credit ratings are statistically different, I analyzed paired ratings data using parametric and non-parametric tests. For the Table 2 presentation, I combined the 2001 and 2002 data. As a result, I 
compared pairs of KBRA and Moody's credit ratings for each year from 2001 through 2012, inclusive. As an example, I located KBRA BFSRs and Moody's credit ratings on 12 financial intuitions for 2003. I converted the qualitative ratings to a quantitative measure using Moody's WARF methodology. I then compared the WARFs of the twelve pairs of ratings. I conducted a Wilcoxon Signed rank test and paired t-test on the paired data. For the twelve periods displayed in Panel B, the Wilcoxon test indicates a statistical significance of $1 \%$ in each period and the paired t-test indicates a statistical significance of at least $5 \%$ in ten out of the twelve periods of study. This means that, in 11 of the 12 periods studied, KBRA BFSRs and Moody's Credit ratings are significantly different.

The third and last set of tests involved the comparison of Moody's BFSRs and Moody's Credit ratings. As both ratings are from Moody's, this set of tests is an intra-NRSRO comparison. As was highlighted in the above univariate analysis section, the average Moody's BFSR was higher than the average Moody's credit ratings in each of the 45 quarters during the 2001-2012 period. To determine whether the differences are statistically different, I analyzed paired ratings data. To accomplish this, I compared pairs of Moody's BFSRs and Moody's credit ratings for each year from 2001 through 2012, inclusive. For example, I located Moody's BFSRs and Moody's credit paired ratings on 26 financial intuitions for 2003. I converted the qualitative ratings to a quantitative measure using Moody's WARF methodology. I then compared the WARFs of the 26 pairs of ratings. I conducted a Wilcoxon Signed rank test and paired t-test on the paired data. For the twelve periods displayed in Table 2, the Wilcoxon test indicates statistical significance of $1 \%$ level in each of the 12 periods. The paired t-test indicates statistical significance of at least $5 \%$ in 11 of the 12 periods studied. It also indicates a statistical significance of at least $10 \%$ in each of the 12 periods.

Overall, the parametric and non-parametric test results have consistent results. The three sets of parametric tests resulted in statistical significance of at least 0.10 in 27 of the 36 tests. Similarly, the three sets of non-parametric tests resulted in statistical significance of at least 0.10 in 27 of the 36 tests. I provide a histogram of the $72 p$-value results in Table 2 as follows:

As Figure 4 indicates, the most common result of the 72 Wilcoxon and t-tests is a $p$-value $<0.01$. This occurred 43 times (out of 72 tests). Four times the test resulted in a $p$-value greater than 0.01 , but less than 0.05 , and seven times the test resulted in a $p$-value greater than 0.05 , but less than 0.10 . Eighteen times the test resulted in a $p$-value greater than 0.10 and, thus, is not statistically significant.

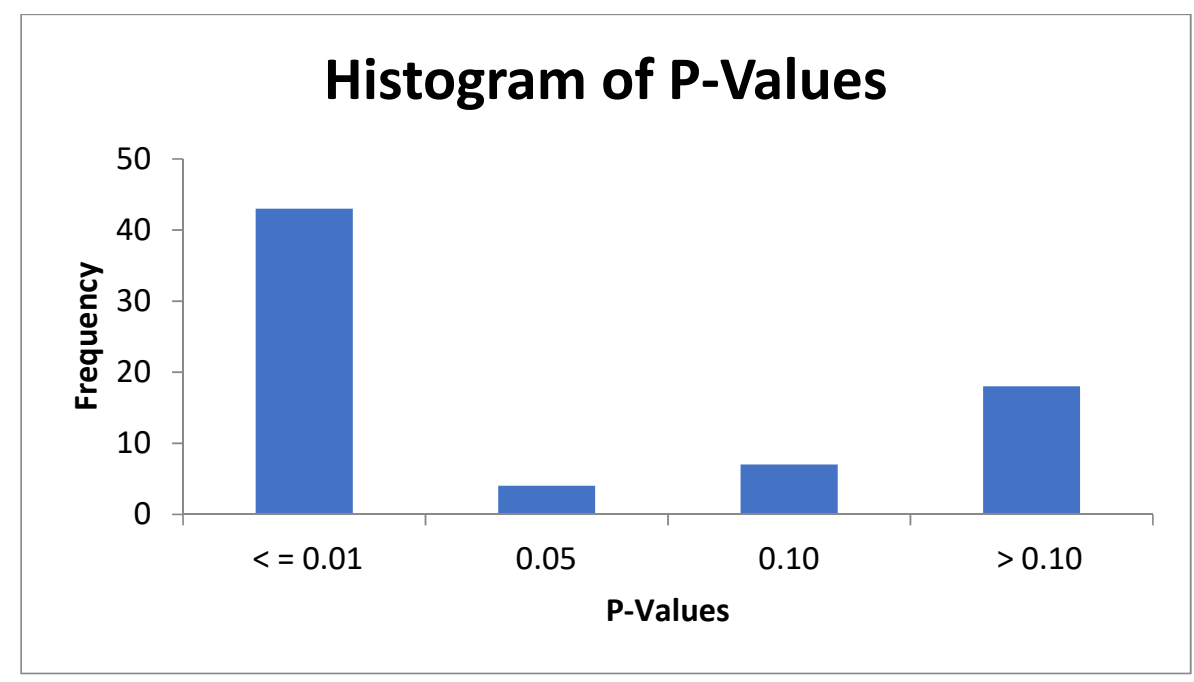

Figure 4. Histogram of Table $2 p$-Values. 


\section{Hypothesis Discussion}

I find mixed evidence in support of Hypothesis 1 that KBRA and Moody's have consistent BFSRs over time. The KBRA and Moody's portfolio WARFs have a $+78 \%$ Pearson's correlation coefficient over the 2002-2012 period. The high degree of association with one another over such a long period indicate that the same factors may have influenced both sets of ratings. The high degree of association supports Hypothesis 1 . In contrast, the KBRA BFSRs were higher than Moody's BFSRs in 33 out of $45(73.33 \%)$ quarters for the data studied. This provides evidence that KBRA ratings were more conservative during the period studied. Using a Wilcoxon paired test, the KBRA ratings were statistically different from the Moody's ratings in three out of twelve periods at a significant level of at least $10 \%$. Furthermore, the paired t-tests indicate statistical significance of at least $10 \%$ in four out of twelve periods studied. This indicates that the KBRA ratings utilized methodologies, data and/or variables differently and more conservatively than Moody's during the period of study.

I find strong support for Hypothesis 2 that BFSRs are more conservative than credit ratings. When I compared KBRA BFSRs to Moody's credit ratings, I found that the BFSRs were consistently lower. Over 45 quarters from 2001 through 2012, KBRA BFSRs had a higher WARF than the Moody's credit ratings in every period. The average KBRA BFSR over the 2001-2012 period is closest to a Ba3 rating while the average Moody's credit rating over the same period is closest to an A2 rating. Similarly, the average Moody's BFSR over the 2001-2012 period is closest to a Ba2 rating. This means that the KBRA and Moody's BFSRs had an average rating seven rating notches and six rating notches lower than the Moody's credit rating, respectively. These rating differences provide support for Hypothesis 2 that BFSRs are more conservative than credit ratings. In addition, I tested the differences between KBRA BFSRs and Moody's credit ratings for statistical significance. As is detailed in Section 3, I found significant differences in each period tested at a $p$-value of $5 \%$ using a Wilcoxon paired test. I also found significance differences in 11 of the 12 periods tested at a $p$-value of at least $5 \%$ using a paired $\mathrm{t}$-tests. When I compared Moody's BFSRs to Moody's credit ratings using the Wilcoxon signed rank test and paired t-tests, I also found strong support for Hypothesis 2. Specifically, I found significant differences in each of the 12 periods tested at a $p$-value of $1 \%$ using a Wilcoxon paired test. I also found significant differences in 11 of the 12 periods tested at a $p$-value of at least $5 \%$ using a paired t-test.

\section{Conclusions}

This research focuses on BFSRs, which are a specialized type of NRSRO rating for banking institutions. Since BFSRs reflect the unique structure of banking institutions, the research results offer valuable information about rating agencies and banking institutions. In this research, I detailed how BFSRs from different NRSROs compare to one another. I also compared BFSRs to credit ratings. To my knowledge, no prior research has ever compared BFSRs to credit ratings or compared BFSRs from two different rating agencies. If true, this research is unique and its findings add significantly to the body of knowledge on banking institutions and rating agencies.

Several relationships were evident when comparing BFSR and credit rating data. First, ratings from two different agencies were highly correlated with one another. While some degree of correlation is to be expected, it was unexpected that the ratings moved in near lockstep with one another. Second, different types of ratings from the same rating agency also moved in lockstep with one another. While different rating methodologies are applied to BFSRs and general credit ratings, the high correlation indicates similar methodologies. Third, BFSRs indicate more credit risk than general credit ratings on the same set of financial institutions. I calculated the average BFSR rating during the 2001-2012 period of $\mathrm{Ba} 2$ and $\mathrm{Ba} 3$ for Moody's and KBRA, respectively. This compares to an average Moody's credit rating of A2 for the same set of financial institutions over the same period. This means that BFSRs indicate that banks had more credit risk than the corresponding credit ratings over the period studied. Fourth, BFSRs started increasing soon after the 
start of the financial crisis in 2008 and 2009 while credit ratings did not increase nearly as much during the same period. The KBRA and Moody's BFSR WARFs increased by $253.0 \%$ and $71.3 \%$, respectively, from 1st quarter of 2008 to the 4th quarter of 2009. The Moody's credit rating WARF increased by only $24.7 \%$ during the same period. This indicates that BFSRs may have provided an earlier indication of the pending credit crisis prior to credit ratings. Fifth, KBRA BFSRs are more conservative than Moody's credit ratings. The KBRA BFSR WARF was higher than the Moody's BFSR WARF in 33 of the 45 quarters studied. It also had statistically different ratings in four out of twelve years when pairs of rating data were tested using a Wilcoxon signed rank test. The above conclusions have importance to businesses, as they would want to know the risk of the banking institutions with which they transact. It is also important for market participants who either lend to or invest in banking institutions. Lastly, the above rating differences have implications for regulators and policy makers that supervise banking institutions and guide the institutions towards safety and soundness.

Significant limitations exist in this research. The data utilized covers the period 2001 to 2012. Unfortunately, Moody's has discontinued issuing and maintaining BFSRs, which means the data cannot be updated. Moreover, the KBRA data was accessed using a onetime subscription. I would need an additional subscription to update the data. It would be beneficial to update the data, but due to the above restrictions I am unable to do so.

The fundamental questions addressed by this research is how do different types of ratings compare to one another and how do the same types of ratings from different rating agencies compare to one another. What does it tell us that BFSR ratings from different NRSROs were highly correlated and move in lock step with one another? What does it tell us that BFSRs were more conservative than credit ratings over the period studied? Which NRSRO has BFSRs, which more accurately reflected the risk of the financial institutions? Does a similar relationship hold for BFSRs in different periods studied? These are questions for, and the potential direction of, future research.

Funding: This research received no external funding.

Data Availability Statement: Restrictions apply to the availability of these data. Data was obtained from a Kroll Bond Ratings subscription and a Bloomberg terminal subscription.

Conflicts of Interest: The author declares no conflict of interest.

\section{Appendix A}

Table A1. Panel A-KBRA BFSR Definitions. The below table provides a list of the KBRA BFSRs. It also provides a description of the ratings that KBRA assigns to financial institutions. The first column provides the alphabetical rating and the second column provides a corresponding description.

\begin{tabular}{cl}
\hline KBRA Rating & \multicolumn{1}{c}{ Rating Description } \\
\hline A & $\begin{array}{l}\text { An institution in strong financial condition that is well capitalized, liquid } \\
\text { and profitable. The entity is highly likely to meet its credit obligations } \\
\text { under severe economic, financial and business conditions. }\end{array}$ \\
\hline B & $\begin{array}{l}\text { An institution in sound financial condition that is likely to meet its credit } \\
\text { obligations under difficult economic, financial and business conditions. }\end{array}$ \\
\hline C & $\begin{array}{l}\text { An institution with an adequate financial condition but is more susceptible } \\
\text { to adverse changes in economic conditions that could affect its ability to } \\
\text { meet its credit obligations. }\end{array}$ \\
\hline D & $\begin{array}{l}\text { An institution whose financial condition is judged to be relatively weak } \\
\text { and its ability to meet financial obligations could be affected by adverse } \\
\text { economic, financial or business conditions. }\end{array}$ \\
\hline
\end{tabular}


Table A1. Cont.

\begin{tabular}{|c|c|}
\hline KBRA Rating & Rating Description \\
\hline E & $\begin{array}{l}\text { An institution that is likely to have financial problems and poor financial } \\
\text { ratios. Careful consideration should be made concerning investments in } \\
\text { this institution. The institution has a much higher probability of failure } \\
\text { than institutions with higher ratings. }\end{array}$ \\
\hline NB & $\begin{array}{l}\text { A new institution which is less than three years old and which is not rated, } \\
\text { but its financial data is presented and an "NB" is shown in the rating field. }\end{array}$ \\
\hline NR & $\begin{array}{l}\text { An atypical bank or institution that is missing key financial data necessary } \\
\text { to derive a rating. }\end{array}$ \\
\hline \multicolumn{2}{|c|}{$\begin{array}{l}\text { In addition, the above ratings and descriptions KBRA may also include a " }+ \text { " or " }- \text { " to signify a stronger (+) } \\
\text { rating or weaker rating (-) in the A through } \mathrm{C} \text { rating categories. KBRA may rate a given institution "B+", "B' } \\
\text { or "B-". For example, a "B+" rating would be assigned to an institution that has less risk (or is stronger) than } \\
\text { the overall "B" rating. Conversely, a "B-" rating would be assigned to an institution that has higher risk (or is } \\
\text { weaker) than the overall " } \mathrm{B} \text { " rating. }\end{array}$} \\
\hline
\end{tabular}

Table A2. Panel B-Moody's BFSR Definitions. The below table provides a list of the Moody's BFSRs. It also provides a description of the ratings that Moody's assigns to financial institutions. The first column provides the alphabetical rating and the second column provides a corresponding description.

\begin{tabular}{|c|c|}
\hline Moody's Rating & Bank Financial Strength Rating Definitions \\
\hline A & $\begin{array}{l}\text { Banks rated A possess superior intrinsic financial strength. Typically, they } \\
\text { will be institutions with highly valuable and defensible business franchises, } \\
\text { strong financial fundamentals, and a very predictable and stable operating } \\
\text { environment. }\end{array}$ \\
\hline B & $\begin{array}{l}\text { Banks rated B possess strong intrinsic financial strength. Typically, they } \\
\text { will be institutions with valuable and defensible business franchises, good } \\
\text { financial fundamentals, and a predictable and stable operating } \\
\text { environment. }\end{array}$ \\
\hline $\mathrm{C}$ & $\begin{array}{l}\text { Banks rated C possess adequate intrinsic financial strength. Typically, they } \\
\text { will be institutions with more limited but still valuable business franchises. } \\
\text { These banks will display either acceptable financial fundamentals within a } \\
\text { predictable and stable operating environment, or good financial } \\
\text { fundamentals within a less predictable and stable operating environment. }\end{array}$ \\
\hline $\mathrm{D}$ & $\begin{array}{l}\text { Banks rated D display modest intrinsic financial strength, potentially } \\
\text { requiring some outside support at times. Such institutions may be limited } \\
\text { by one or more of the following factors: a weak business franchise; } \\
\text { financial fundamentals that are deficient in one or more respects; or an } \\
\text { unpredictable and unstable operating environment. }\end{array}$ \\
\hline $\mathrm{E}$ & $\begin{array}{l}\text { Banks rated E display very modest intrinsic financial strength, with a } \\
\text { higher likelihood of periodic outside support or an eventual need for } \\
\text { outside assistance. Such institutions may be limited by one or more of the } \\
\text { following factors: a weak and limited business franchise; financial } \\
\text { fundamentals that are materially deficient in one or more respects; or a } \\
\text { highly unpredictable or unstable operating environment. }\end{array}$ \\
\hline Note: & $\begin{array}{l}\text { Where appropriate, a "+" modifier will be appended to ratings below the } \\
\text { "A" category and a "- " modifier will be appended to ratings above the " } \mathrm{E} \text { " } \\
\text { category to distinguish those banks that fall in the higher and lower ends, } \\
\text { respectively, of the generic rating category }\end{array}$ \\
\hline
\end{tabular}


Table A3. Panel C: KBRA Bank Financial Strength Ratings Mapping. This table provides a complete list of KBRA BFSRs, Moody's BFSRs and their corresponding Moody's Credit rating and corresponding weighted average rating factor (WARF) measure. WARF is a quantitative measure of each qualitative BFSR and credit rating.

\begin{tabular}{|c|c|c|c|}
\hline KBRA BFSR & Moody's BFSR & Moody's Credit Rating & WARF \\
\hline $\mathrm{A}+$ & A & Aаa & 1 \\
\hline $\mathrm{A}$ & & Aa1 & 10 \\
\hline \multirow[t]{2}{*}{$A-$} & $\mathrm{A}-$ & $\mathrm{Aa} 2$ & 20 \\
\hline & & $\mathrm{Aa} 3$ & 40 \\
\hline $\mathrm{B}+$ & $\mathrm{B}+$ & A1 & 70 \\
\hline $\mathrm{B}$ & $\mathrm{B}$ & A2 & 120 \\
\hline \multirow[t]{2}{*}{$\mathrm{B}-$} & $\mathrm{B}-$ & A3 & 180 \\
\hline & & Baa1 & 260 \\
\hline \multirow[t]{2}{*}{$\mathrm{C}+$} & $\mathrm{C}+$ & Baa2 & 360 \\
\hline & & Baa3 & 610 \\
\hline \multirow[t]{3}{*}{$\mathrm{C}$} & $\mathrm{C}$ & Ba1 & 940 \\
\hline & & $\mathrm{Ba} 2$ & 1350 \\
\hline & & $\mathrm{Ba} 3$ & 1760 \\
\hline \multirow[t]{2}{*}{$\mathrm{C}-$} & $\mathrm{C}-$ & B1 & 2220 \\
\hline & $\mathrm{D}+$ & B2 & 2720 \\
\hline \multirow[t]{4}{*}{$\mathrm{D}$} & $\mathrm{D}$ & B3 & 3490 \\
\hline & $\mathrm{D}-$ & Caa1 & 4770 \\
\hline & $\mathrm{E}+$ & Caa2 & 6500 \\
\hline & & Caa3 & 8070 \\
\hline $\mathrm{E}$ & $\mathrm{E}$ & $\mathrm{Ca}$ & 10,000 \\
\hline
\end{tabular}

Source: Kroll Bond Rating Agency (KBRA) website (krollbondratings.com, accessed on 10 August 2021) and Moody's investors service website (moodys.com, accessed on 10 August 2021).

\section{References}

Beaver, William H., Catherine Shakespeare, and Mark T. Soliman. 2006. Differential properties in the ratings of certified versus non-certified bond-rating agencies. Journal of Accounting and Economics 42: 303-34. [CrossRef]

Bongaerts, Dion K. J., Martijn Cremers, and William N. Goetzmann. 2012. Tiebreaker: Certification and multiple credit ratings. The Journal of Finance 67: 113-52. [CrossRef]

Cantor, Richard, and Frank Packer. 1997. Differences of opinion and selection bias in the credit rating industry. Journal of Banking $\mathcal{E}$ Finance 21: 1395-417.

Demirgüç-Kunt, Asli, Enrica Detragiache, and Thierry Tressel. 2008. Banking on the principles: Compliance with Basel Core Principles and bank soundness. Journal of Financial Intermediation 17: 511-42. [CrossRef]

Gaillard, Norbert. 2012. Fitch, Moody's, and S\&P Sovereign Ratings and EMBI Global Spreads: Lessons from 1993-2007. In A Century of Sovereign Ratings. New York: Springer, pp. 149-70.

Gluck, Jeremy, Helen Remeza, and Gus Harris. 2000. Moody's approach to rating multisector cdos. Moody's Structured Finance Special Report, September 15.

Gogas, Periklis, T. Papadimitriou, and Anna Agrapetidou. 2014. Forecasting bank credit ratings. The Journal of Risk Finance 15: 195-209. [CrossRef]

Hammer, Peter L., Alexander Kogan, and Miguel A. Lejeune. 2012. A logical analysis of banks' financial strength ratings. Expert Systems with Applications 39: 7808-21. [CrossRef]

Hrvatin, Richard, Matthias Neugebauer, and Gareth Stoyle. 2006. The analysis of short-term rating migration in synthetic CDOs. The Journal of Structured Finance 12: 20-27. [CrossRef]

$\mathrm{Hu}$, Jian. 2007. Assessing the Credit Risk of CDOs Backed by Structured Finance Securities: Rating Analysts' Challenges and Solutions. The Journal of Structured Finance 13: 43-59. [CrossRef]

Huang, Yu-Li, and Chung-Hua Shen. 2015. The sovereign effect on bank credit ratings. Journal of Financial Services Research 47: $341-79$. [CrossRef] 
Jewell, Jeff, and Miles Livingston. 1999. A comparison of bond ratings from Moody's S\&P and Fitch IBCA. Financial Markets, Institutions $\mathcal{E}$ Instruments 8: 1-45.

Johnson, Richard. 2004. Rating agency actions around the investment-grade boundary. The Journal of Fixed Income 13: 25-37. [CrossRef]

Mathis, Jerome, James McAndrews, and Jean-Charles Rochet. 2009. Rating the raters: Are reputation concerns powerful enough to discipline rating agencies? Journal of Monetary Economics 56: 657-74. [CrossRef]

Morningstar. 2017. U.S. CLO Ratings Methodology. In Morningsar Ratings. New York: Morningstar Credit Ratings, LLC.

Öğüt, Hulisi, M. Mete Doğanay, N. Nildağ Başak Ceylan, and R. Aktaş. 2012. Prediction of bank financial strength ratings: The case of Turkey. Economic Modelling 29: 632-40. [CrossRef]

Partnoy, Frank. 1999. The Siskel and Ebert of financial markets: Two thumbs down for the credit rating agencies. Wash. ulq 77: 619. [CrossRef]

Partnoy, Frank. 2002. The paradox of credit ratings. In Ratings, Rating Agencies and the Global Financial System. Boston: Springer, pp. 65-84.

Partnoy, Frank. 2017. What's (Still) Wrong with Credit Ratings. Washington Law Review 92: 1407. [CrossRef]

Peresetsky, A., and A. Karminsky. 2008. Models for Moody's Bank Ratings. Bank of Finland, Discussion Papers No. 17, BOFIT, Helsinki. Available online: https://ideas.repec.org/p/pra/mprapa/34864.html (accessed on 10 August 2021).

Poon, Winnie P., Michael Firth, and Hung-Gay Fung. 1999. A multivariate analysis of the determinants of Moody's bank financial strength ratings. Journal of International Financial Markets, Institutions and Money 9: 267-83. [CrossRef]

Poon, Winnie P., Junsoo Lee, and Benton E. Gup. 2009. Do solicitations matter in bank credit ratings? Results from a study of 72 countries. Journal of Money, Credit and Banking 41: 285-314. [CrossRef]

Reusens, Peter, and Christophe Croux. 2017. Sovereign credit rating determinants: A comparison before and after the European debt crisis. Journal of Banking \& Finance 77: 108-21.

Ruddy, John A. 2018a. Using a US Bank Regulatory Approach to Explain Bank Financial Strength Ratings. Journal of Corporate Accounting E Finance 29: 70-82.

Ruddy, John A. 2018b. The Relation of Financial Markets and Bank Financial Strength Ratings. Paper presented at 2018 FMA Conference: Annual Meeting, San Diego, CA, USA, October 10-13. 